\title{
Geochemical Study of Oil Shales Sargelo Formation in Kuh-e Kaino Section (Northern Masjed-Soleiman), Iran
}

\author{
Borzu Asgari Pirbalouti*, Mahsa Moayeripour \\ Department of Petroleum Engineering Masjed-Soleiman Branch, Islamic Azad University, Masjed-Soleiman, Iran \\ Email: ‘asgariborzu@gmail.com, moayeripour@yahoo.com
}

How to cite this paper: Pirbalouti, B.A. and Moayeripour, M. (2017) Geochemical Study of Oil Shales Sargelo Formation in Kuh-e Kaino Section (Northern MasjedSoleiman), Iran. Open Journal of Geology, 7, 83-92.

http://dx.doi.org/10.4236/ojg.2017.71006

Received: December 8, 2016

Accepted: January 17, 2017

Published: January 20, 2017

Copyright $\odot 2017$ by authors and Scientific Research Publishing Inc. This work is licensed under the Creative Commons Attribution International License (CC BY 4.0).

http://creativecommons.org/licenses/by/4.0/ (c) (i) Open Access

\begin{abstract}
Oil (bituminous) shales source rocks with variable amounts of solid kerogen type II are the conditions for changing the oil that is not provided for them. Each of these shales affected in temperature about 150 to 170 gallons of oil produced. Therefore by reducing hydrocarbon resources, it can be a good energy source for the future. To study the geochemistry of this shale, one section of outcrops in the Kuh-e Kaino (Northern Khozestan) was selected which was located in the central Zagros. Chemical analysis and thin sections were prepared from samples of carbonate shale. These deposits with a thickness of 115 $\mathrm{m}$ of the Lower Jurassic formations Neyriz and Sargelo relative age and their relationship are gradual and interfinger. The upper border after an erosional unconformity, Fahliyan Formation of Lower Cretaceous age on them covered. Analysis results show that the percentage of organic matter this shales in Kuh-e Kainois is equivalent to 8.44 percent. The index has gained economic value of metal elements $\mathrm{Sr}, \mathrm{V}, \mathrm{Ba}, \mathrm{Ni}$, and also has economic value. Bituminous materials formed stabilize in shaley source rock of Sargelo formation, but not with continuous deposition on them, as a result of temperature and pressure not increasing and immature kerogen. The causes of this event are as follows: the basin tectonic condition, Stratigraphy position and faults activity in the basin.
\end{abstract}

\section{Keywords}

Geochemistry, Oil Shale, Sergalu Formation, Kuh-e Kaino, Kerogen

\section{Introduction}

Shales sedimentary contains rocks of black shales with organic material and decomposed into oil or natural gas by thermal, making it the most important source for oil and gas deposits in the world. 
The black shale composed of fine particles of organic material which accumulated between clay particles [1]. When the clay sediments (shales) and organic material with sedimentation over them, are buried deep enough the increase of temperature and pressure made the organic material into oil and gas. Therefore, oil and gas due to the low density and internal pressure of the source rock (shale) migrate upward to the massive sedimentary. Oil and gas are often in the pore spaces in a single upper stone such as sandstone trapped and in fact it rock reservoirs is called [2] [3] [4]. Oil shales contain considerable quantities of organic material miss conditions of oil and gas and finally, in the early stages remained kerogen of the first type and has a high proportion of $\mathrm{H} / \mathrm{C}$ and low $\mathrm{O} / \mathrm{C}$ and were mainly of origin Lipeddar algal [5] [6] [7].

The extractable hydrocarbons in oil shales are about $4 \%$ to over $50 \%$ to the weight of the rocks ratio. That is between 10 to 150 gallons of oil in one ton rock or 50 to 700 liters per hundred into 1000 kilograms rock, which sometimes reaches this amount to 170 gallons. In oil shales millions of years ago, the deposition of clay with layers of organic remains in lake and marine sediments of the upper and temperature along with pressure factors have arisen [8]. Extracting oil from bituminous shales is so much complex than extracting conventional oil in shale oil Materials are solid and cannot be directly pumped to the surface earth. Oil shales must first be extracted and then exposed to high temperatures (about $350^{\circ} \mathrm{C}$ to $500^{\circ} \mathrm{C}$ ); this operation is called rectification that during this process, the kerogen conversed to oil and then output collected liquid oil. Recoverable store of the oil shales over 2000 billion barrels in the world is estimated to be the highest in Central American States [7] [9] [10]. Previous studies about history of oil shale (bituminous) and source rock are as follows: Buskmand Mayo suggested origin of hydrocarbon field in Masjed-Soleiman; later Richardson (1942) proposed the origin of Asmari formations oil as the biochemical limestone; Thomas (1950) also confirmed the same opinion and even suggested Gachsaran formation known as the origin of part of the Asmari oil [11]. But those beliefs are in conflict with deep origin for oils Asmari was also previously suggested. Less said the Zagros various source rocks exist, and in this case the bitumenbearing rocks in the Cretaceous-Eocene and Jurassic referred to as shales containing significant Posidonia reported (Less, 1950) stated that the origin of the oils in thousands of meters deeper there and vertical migration to Asmari to be admitted [12] [13] [14] [15]. The same idea was expressed for Karkuk reservoirs in northern Iraq. This idea later by Henson (1950), which was mostly emphasized by Dunninton (1958), suggested that Iran's Asmari oil on immigration crude oil accumulated in the lower and middle Cretaceous reservoirs have been achieved [16] [17].

Oil operating companies launched a project which conducted by Bordenave and Nili [4] the project objectives were as follows:

1) Specification and publication of source rocks in the Zagros Basin.

2) The relationship between crude oil and source rocks.

3) Hydrodynamic and its impact on oil migration. 
4) Paleo-tectonic in order to understand the migration and folding's.

Nili and Bordenave about 1500 samples of outcrops sediments of Zagros (Cambrian to Upper Miocene) geochemistry were analyzed [3] [8] [11]. Nili and Bordenave studied oil power generating source rocks in the Zagros based on mathematical models and the foundations of the modern geochemistry [4]. Fortytwo samples of crude oil from Cretaceous, Tertiary and Triassic, and three samples of crude oil from northeast Iraq through geochemical and sulfur isotope ratio S34/S32 were studied [18]. Burwood (1976), the geochemist in particular oil service companies (consortium), studied 300 samples of crude oil and source rock who proposed results about evaluating and development of source rock [19]. Young et al. (1977) evaluated the age of stored oils in Asmari and Sarvak Formation [20]. Ala (1980) performed his doctoral thesis on oil geology in the Zagros Basin with special attention to geochemistry of source rock [21]. Ala et al. (1980) also studied organic geochemical properties of oil source rock in the Zagros basin [22], reporting features oil shale (Bituminous) in the Zagros region [23].

\section{Research Necessarily}

A: With stratigraphic studies of oil shale sediments in the area of Zagros can be thick sequence of shales and tar thickness is measured.

B: So also with geochemistry studies of oil shales can be assay achieved hydrocarbon and the other elements.

C: Long-term operation of oil and gas reservoirs in country causing and thus reduce the ever-increasing fossil fuels in the near future oil shale will be highly appreciated.

\section{The Geographical Location of the Study Area}

Oil shale studies in Central Zagros (North Masjed-Soleiman) after a field survey to help map the geological and geographical area, one section in Kuh-e Kaino, northern Khuzestan were selected. Road access to the region by road MasjedSoleiman-Shahr-ekord route Bazoft is possible that within about $90 \mathrm{~km}$ of the route passes near Taraz, north of the appear to be studied (Kino) mountain range. The rest of the route to the desired location about $12 \mathrm{~km}$ dirt road about 7 $\mathrm{km}$ walk is done (Figure 1). Coordinates the study section is: $49^{\circ} 40^{\prime} 32^{\prime \prime}$ east longitude and $32^{\circ} 26^{\prime} 18^{\prime \prime}$ north latitude, it should be noted that the study area within a Shahr-ekord geological map of 1:250,000 placed.

\section{Method Study}

The methodology of this study consists of several stages that include library studies, field, geochemical laboratory and field studies measured the actual thickness classes, systematic sampling, measurement slope and the along bedding, determine the geographical location by GPS and describing lithology of which 80 samples were taken manually, from which 40 samples were prepared microscopic sections and 40 samples of bitumen shales determination of the chemical analysis of organic substances and metals were sent to laboratory. 


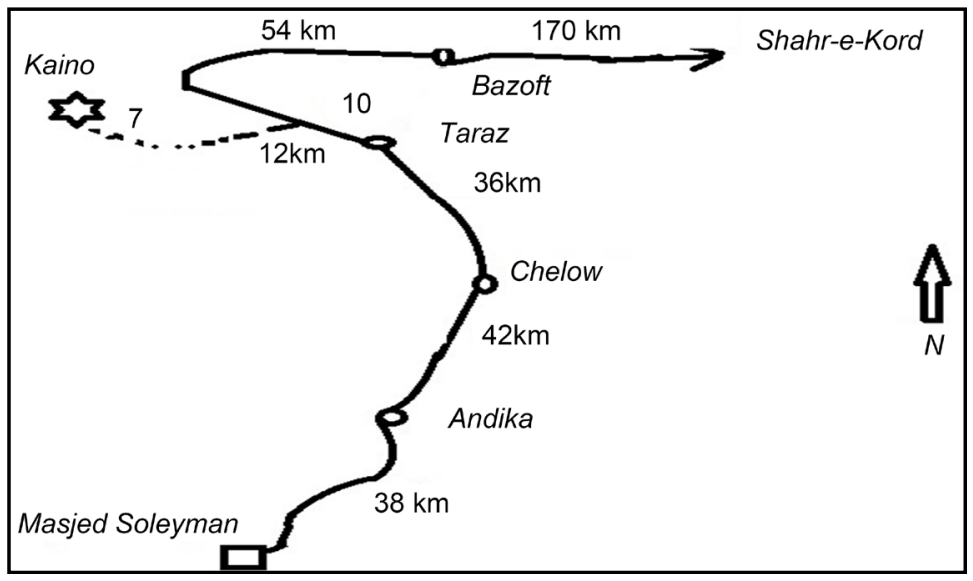

Figure 1. Map of the studied ways to access the incision site.

\section{Discussion}

The stratigraphy of the regional observes:

According to stratigraphic studies on oil shales Kuh-e Kainosection in the north of Masjed Soleyman was found, although geological map it to have left a special formation. But this place deposits equivalent Neyriz formations and Sargelo is lower Jurassic age. Lithology of formation in this section are above as follows oil shale facies classes (Figure 2) Is Sergalu formation Jurassic sediments including Neyriz and Sargelo formations covering the dolomitic Khaneh-kat formation and so upper this deposits coat them with unconformity by high limestone cliffs maker, Fahliyan formation with Lower Cretaceous cover (Figure 3). The true thickness of sediments from the base to the apex of 115 meters, uniformity of between 17 and 20 degrees north and 50 degrees to the northwest-southeast along the beds and steep topography is between of the 37 to 45 degrees the north to northeast and Characteristics of lithology separated to 18 unit. The Lithology description of this sequence (Figure 4) in Kuh-e Kaino section including:

Neyriz Formation:

1. White porous regularly bedding dolomitic limestone with true thickness of 5.8 meters.

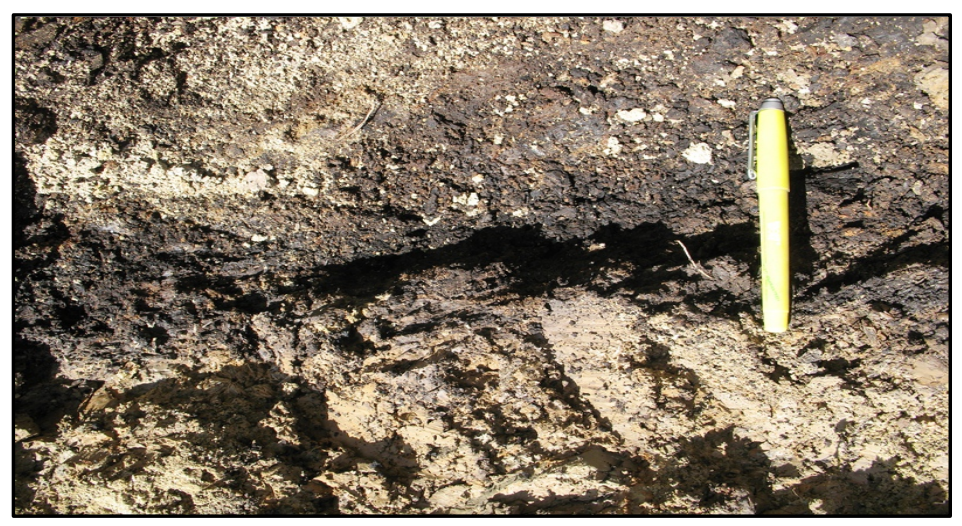

Figure 2. Photo of oil shale layers in Kuh-e kaino section. 


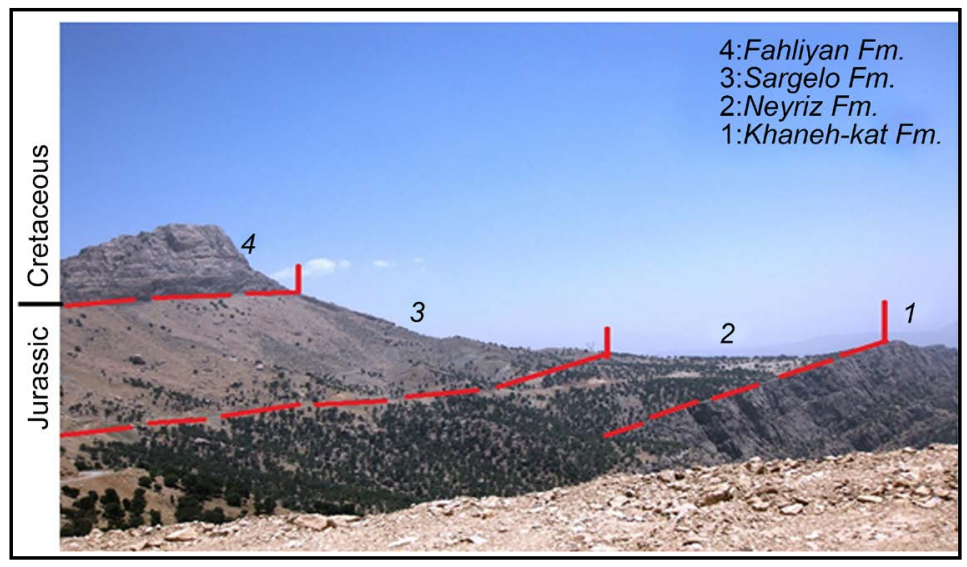

Figure 3. The landscape picture of height Kuh-e Kaino section and the condition stratigraphic formations (see to the south West).

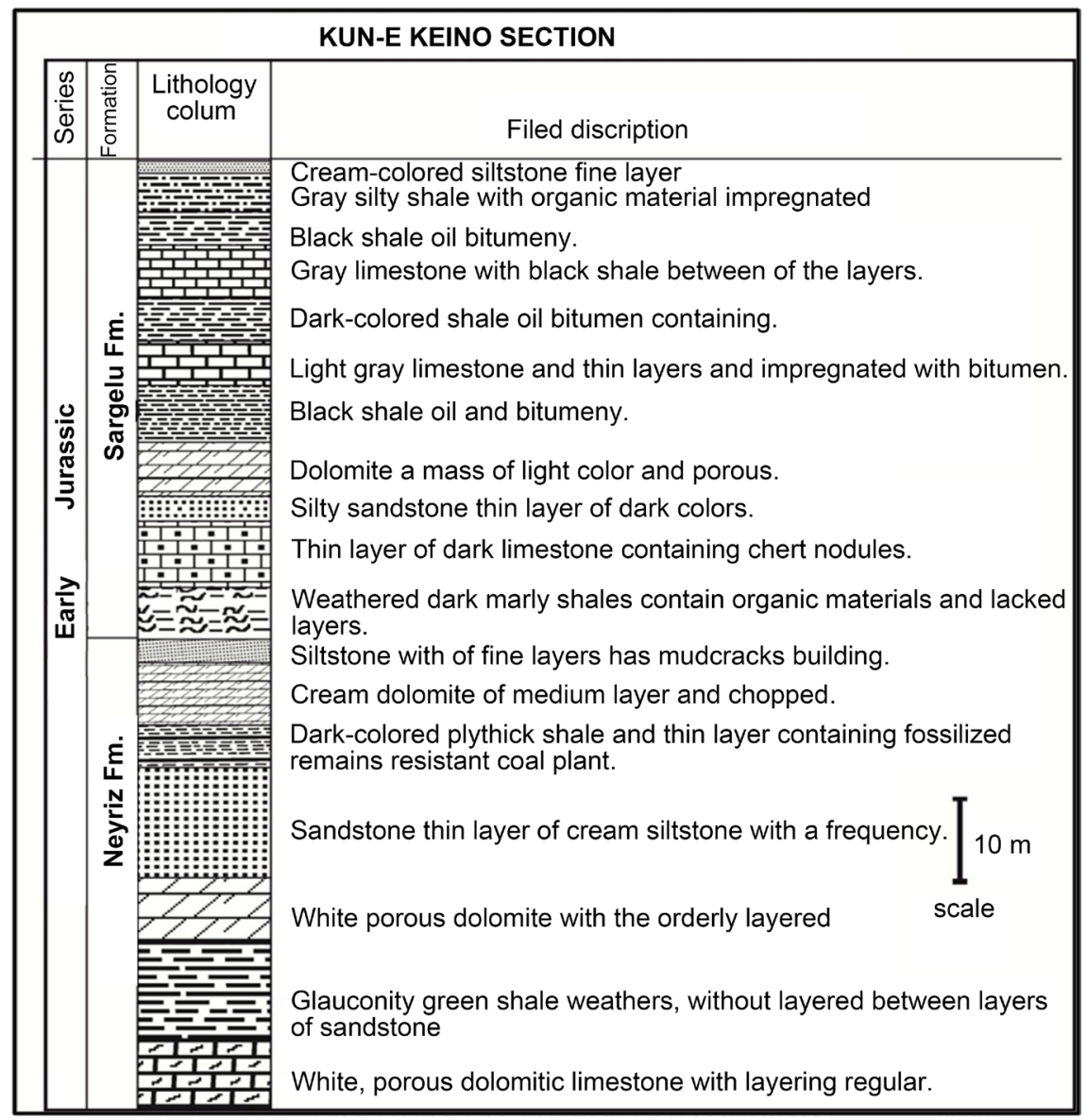

Figure 4. Stratigraphic column of Kuh-e Keino section in the north of the MasjedSoleiman.

2. Glauconitic green weathering shale, lack layered with between layers of cherty sandstone 12 meters.

3. The white porous dolomite layered regular 5.7 meters.

4. Thin layers of sandstone with alternating cream-colored siltstones 14 meters. 
5. Plastic demented dark shales with of the thin layered and fossilized plant remains and coal veins 4 meters.

6. Cream-colored Dolomite middle layer and alternated 8 meters.

7. Siltstone with an elegant layered with mud cracks building 3 meters.

B: Sargelo formation

8. Marly dark shales, weathered with organic material is no layering $6.5 \mathrm{~m}$.

9. Dark-colored thin layer of limestone containing nodules chert 8 meters.

10 Silty thin layer dark sandstone 3 meters.

11 Brightly colored and porous mass dolomite 6.5 meters.

12. Black oil shales (bituminous) 8 meters.

13. Thin layer of light gray limestone and bituminous materials soaked 4.5 meter.

14. Dark oil shales with bituminous material oil 5 meters.

15. Gray limestone with layers of black shale 6.5 meters.

16. Oil shale (bituminous) with black oil 4 meters.

17. Gray silty shale impregnated with organic materials, 4 meters.

18. The thin layer of cream-colored siltstones 2 meters.

On the last layer of Sargelo formation, the thin layer of cream-colored siltstones, attrition red sandstones and thick layer cream colored to light gray limestone building are belonging to the Lower Cretaceous age Fahliyan formation. Based on the lithological sequence and study area thickness beds, the section in the shape (4) were drawn of the stratigraphic column. The oil shales are often in lake and marine deposits, although environment origin were attributed into the shales relatively deep, but now, it is thought that deposition in relatively shallow temporary ponds are often exposed to drying can also form a favorable environment for them [24]. The exact amount of organic matter needed for a shale as oil shale standings contracts and limit value of 9 percent cited an increase in the amount of organic matter oil shale, coal tar becomes a figure of $27 \%$ as critical value of the shale of bituminous (tar) and coal tar can be considered. Metal enriched, chemical deposition and water washed of components mineral are formed with host rocks or by moving water penetration or brought up in shale formations organic ligands fall into the trap and deposits, this quarry time deposits in shallow coastal and deep-sea environments are formed.

For the formation of these deposits materials in solution are deposited into the environment, where water-insoluble compounds formed by ionic, chemical deposition takes place, Of course, to form a valuable ore sedimentary have accumulated high minerals oil shale (bituminous). The controller settling vaml $\mathrm{Ph}$ and Eh depositional environment that inhabit the waters of these two factors is low [7]. Iran's Zagros Basin is related oil shale in Jurassic-Cretaceous age and to open marine environments such that it can be noted that in this study Sargelu reserves have been studied. Zagros oil shale outcrops in the vicinity of large faults along them can be seen that the most important areas of the central Zagros can be noted around Zard Kuh-e Bakhtiyari, Bazoft and North Masjed-Soleiman. Some adjacent sedimentary basins such as the Sanandaj-Sirjan with volcanic arcs 
and fluids particles and sediment transport Kalat within the basin water transfer place, one of the important reasons for having oil shale (bituminous) of the elements heavy metal, organic ligand affinity heavy metal enrichment is sent on the other hand oil shale (bituminous).

The combination of oil shales (bituminous) can be classified as a subgroup.

1. Mineral less than 90 percent of detrital components (quartz-Fldspar-Mica-Carbonates-clay-pyrite-minor minerals).

2. Organic materials are 10 to 27 percent which contains bitumines (hydrocarbon soluble $2 \%$ and $8 \%$ soluble kerogen)

Oil shale (bituminous) Sargelu formation of high economic value and benefit in the future due to increasing demand industry that they can be exploited.

The geochemical analyzes performed on 40 samples, were identified the percentage of organic materials and metallic and nonmetallic elements in Table 1.

Average analysis Sargelu Formation, are the main elements of hydrocarbon groups include $\left(\mathrm{S}, \mathrm{H}_{2} \mathrm{O}+\mathrm{CO}_{2}, \mathrm{C}\right)$ and oxide elements include: $(\mathrm{CaO}, \mathrm{MnO}, \mathrm{CaO}$, $\mathrm{P}_{2} \mathrm{O}_{5}, \mathrm{Fe}_{2} \mathrm{O}_{3}, \mathrm{TiO}_{2}, \mathrm{MgO}, \mathrm{K}_{2} \mathrm{O}, \mathrm{Na}_{2} \mathrm{O}, \mathrm{Al}_{2} \mathrm{O}_{3}$., $\mathrm{SiO}_{2}$ ) and metal elements include: (Ba, Ce, Co, Cr, Cu, Nb, Mo, U, Th, CL, NI, Pb, Rb, Sr, V, W, Y, Zr, Zn) that the percentage of each one of these elements is charged.

By observing the results of geochemical analysis of oil shales in Kuh e-kaino section concludes that the percentage of hydrocarbon in Kuh e-kaino section shales is not very high. This amount is equivalent to 8/44 percent in terms of international standards, shales are that more than 10 percent organic ingredients with economic value and understand that this amount is close to the border and the rate of trace elements in the shale, particularly with metallic elements such as $\mathrm{Sr}, \mathrm{V}, \mathrm{Ba}, \mathrm{Ni}$, has bitumen shales extraction index is considerable and therefore in Kuh e-kaino section dual economic value. Due to the formation of the studied deposit was in Jurassic which in that time basin deposition (Neotethys) developed

Table 1. Results tables of geochemical analysis of oil shales (bituminous) in Kuh e-kaino section.

\begin{tabular}{cccccccccc}
\hline $\mathrm{SiO}_{2}$ & $\mathrm{Al}_{2} \mathrm{O}_{3}$ & $\mathrm{Na}_{2} \mathrm{O}$ & $\mathrm{MgO}$ & $\mathrm{K}_{2} \mathrm{O}$ & $\mathrm{TiO}_{2}$ & $\mathrm{MnO}$ & $\mathrm{CaO}$ & $\mathrm{P}_{2} \mathrm{O}_{5}$ & $\mathrm{Fe}_{2} \mathrm{O}_{3}$ \\
\hline$\%$ & $\%$ & $\%$ & $\%$ & $\%$ & $\%$ & $\%$ & $\%$ & $\%$ & $\%$ \\
42.55 & 9.34 & 0.16 & 2.82 & 1.73 & 0.74 & 0.04 & 9.70 & 0.11 & 7.13 \\
$\mathrm{Ba}$ & $\mathrm{Ce}$ & $\mathrm{Co}$ & $\mathrm{Cr}$ & $\mathrm{Cu}$ & $\mathrm{Nb}$ & $\mathrm{Mo}$ & $\mathrm{U}$ & $\mathrm{Th}$ & $\mathrm{CL}$ \\
$\mathrm{ppm}$ & $\mathrm{ppm}$ & $\mathrm{Ppm}$ & $\mathrm{ppm}$ & $\mathrm{ppm}$ & $\mathrm{ppm}$ & $\mathrm{ppm}$ & $\mathrm{Ppm}$ & $\mathrm{Ppm}$ & $\mathrm{Ppm}$ \\
241 & 63 & 8 & 143 & 24 & 13 & 5 & 8 & 4 & 110 \\
$\mathrm{NI}$ & $\mathrm{Pb}$ & $\mathrm{Rb}$ & $\mathrm{Sr}$ & $\mathrm{V}$ & $\mathrm{W}$ & $\mathrm{Y}$ & $\mathrm{Zr}$ & $\mathrm{Zn}$ & \\
$\mathrm{ppm}$ & $\mathrm{Ppm}$ & $\mathrm{ppm}$ & $\mathrm{ppm}$ & $\mathrm{ppm}$ & $\mathrm{ppm}$ & $\mathrm{ppm}$ & $\mathrm{Ppm}$ & $\mathrm{Ppm}$ & \\
132 & 13 & 62 & 405 & 105 & 4 & 18 & 107 & 94 & \\
Total C & $\mathrm{Total} \mathrm{S}$ & $\mathrm{LOI}$ & & & & & & & \\
$\%$ & $\%$ & $\%$ & & & & & & & \\
8.44 & 0.86 & 16.25 & & & & & & & \\
\hline
\end{tabular}


orogeny. Therefore, the above mention elements could transformed in the stream of magma solution from rift and stored in the fine clay deposition. The same slope of this elements and organic element in coveting stone is indicative of these streams. These deposits section were formed during Jurassic in the time of Sedimentary Basin (Neotethys) development. Thus metal ions along with other elements can be easily displaced volcanic hydrothermal solutions and moved to places where redox conditions are appropriate in sedimentary deposits. Therefore, given that the basin (Neotethys) all necessary conditions have been met and therefore wherever appropriate resuscitation was revival-oxidized metal ions are deposited in sedimentary basins. When the organic material deposits in fine-grained clastic sediments as clays, such as this conditions little by little started chemical reactions and responses to bacterial and microbial and by increasing the thickness of sediments also begins influenced diagenetic process pressure and temperature and therefore also the reaction of organic matter to kerogen becomes the first amount of methane produced the remaining formed kerogen type I or the immature kerogen. This kerogen organic matter of solid and black form that cannot be solved in a solvent and has no resemblance to the original organic matter [10] [24]. However, if the deposition temperature and pressures continue to increase, as a result, large molecules are broken down kerogen and began in the rock the complex process becomes of kerogen Type II or the same mature kerogen. That the petroleum product, but if the operation does not take place as immature kerogen remain in the rock and thus for oil shales in Chile remains rock. Moreover adjacent and proximity of the neo-Tethys (Zagros) basin with geosynclinals of volcano-metamorphic zone Sanandaj-Sirjan belts a second chance to enrich the precious metal and non-metal elements within the shale. As volcanic material could easily land adjacent highlands and moved by the waters into the basinand through submarine fans and pulled into the deeper parts to be replaced. According to studies in this area, prevailed such conditions in the area of the central Zagros. Namely the Lower Jurassic organic matter in sediments enough into the fine-grained clay deposits and reducing conditions governing the premature kerogen on the other hand, Chile also formed during the diagenetic source shale rock but then due to tectonic forces in phaselate Kimmerien and such as activities old faults region especially Mafaron and Sultan Ibrahim faults to bring up region and been stopped rising basin sedimentation.

So that hiatus with a discontinuity has continued to Cretaceous and in Early Cretaceous after a long period of drought again happened Sea Level advanced. As Fahliyan formation by a disconformity is covered Jurassic shale sediments. So after the formed kerogen with reason a stop due to pressure and temperature evolution to kerogen no accepted and as a result of organic material as an immature state, locked inside shale has been steady.

\section{Conclusions}

1) Oil shales deposits in the Kuh-e Kaino section are related to Sargelo formation 
and Lower Jurassic age.

2) Bituminous materials were formed in the shale source of Sargelo formation but because the continuous deposition did not occur on them and the temperature and pressure also did not increase to improve kerogen mature so the organic material remains immature in the form of shale. Tectonic condition and stratigraphic evidence are suitable evidence for this issue.

3) The results of geochemical analysis of oil shales (bituminous) Kuh e-Kaino section show that the percentage of hydrocarbon shales is existence $8 / 44$ percent and the indexes of metal elements $\mathrm{Sr}, \mathrm{V}, \mathrm{Ba}, \mathrm{Ni}$, were higher among others which make it noteworthy.

4) Mafaron and Soltan Ibrahim are old thrust faults in the region that faults along the NW-SE and their activity during the Jurassic, have been playing an important role in the shape, deposition regime, and basin uplift and this rising lead to loss of sedimentation in the middle and upper Jurassic.

5) In addition to performance regional faults, phase Late Kimmerien also influenced the region so that the discontinuity between Sargelo and Fahlian formations role has been constructively important.

\section{Acknowledgements}

This research project was conducted with financial support from Islamic Azad University, Masjed-Soleiman Branch. The authors are grateful to the Islamic Azad University, Masjed-Soleiman Branch, for financial and moral support of the research project.

\section{References}

[1] Busk, H.G. and Mayo, H.T. (1918) Some Notes the Geology of the Persion Oil Fields. Journal of the Institute of Petroleum Technology, 5, 5-26.

[2] Harrison, J.V., Taitt, A.H. and Falcon, N.L. (1932) The Geology of Bakhtiyari Mountain Country IOOC Report No. 455(Unpub.).

[3] Bordenave, M.L., Nili, A.R. and Fozoonmayeh, M.C. (1971) Geochimical Project. Appraisal of Fars province IOOC, Report No, 1182.

[4] Bordenave, M.L. and Nili, A.R. (1973) Geochimical Project Review and Appraisal of the Khuzestan Province IOOC, Report No, 1194.

[5] Sadeghi, K.M., Sadeghi, M.A., Wu, W.H. and Yen, T.F. (1989) Fractionation of Various Heavy Oils and Bitumen for Characterization Based on Polarity. Fuel, 68, 782-787. https://doi.org/10.1016/0016-2361(89)90219-6

[6] Luik, H., Vink, N. and Lindaru, E. (1996) Upgrading of Estonian Shale Oil. 1. Effect of Hydrogenation on the Chemical Composition of Kukersite Retort Oil. Oil Shale, 13, 13-19.

[7] Tikma, L., et al. (2007) Formation of Thermobitumen from Oil Shale by Low Temperature Pyrolysis in an Autoclave. Estonian Academy Publishers, 24, 535-546.

[8] Bordenave, M.L. (1969) Thermal Cracking of Kerogen and the Main Process of oil Generation and Some Consequences for Exploration. IOOC. Report NO.1181.

[9] Tiikma, L., Zaidentsal, A. and Tensorer, M. (2007) About Bituminizing of Kerogen of Oil Shale-Kukersite. Report II/Transactions of Tallinn Polytechnic Institute. Series A. 73, 23-40. 
[10] Tucker, M.E. (2001) Sedimentary Petrology: An Introduction to the Origin of Sedimentary Rocks. Blackwell, Scientific Publication, London.

[11] Thomas, A.N. (1950) The Asmari Limestone of SW Iran. 18th International Geological Congress, London, 25 August-1 September 1948, Part 6, 68-73.

[12] Less, G.M. (1950) The Geology and Tectonics of Oman and Parts of South Eastern Arabia. Quarterly Journal of the Geological Society, 84, 585-670. https://doi.org/10.1144/GSL.JGS.1928.084.01-04.24

[13] Less, G.M. and Richardson, F.D.S. (1940) The Geology of the Oil Field Belt of SW Iran and Iraq. Geological Magazine, 77, 227-251. https://doi.org/10.1017/S0016756800071314

[14] Less, G.M. (1948) Some Structural and Stratigraphical Aspects of the Oil Field of Middle East. 18th International Geological Congress, London, 25 August-1 September 1948, Part 5, 35-44.

[15] Less, G.M. (1950) Some Structural and Stratigraphical Aspects of the oil field of Middle East. 18th International Geological Congress, London, 25 August-1 September 1948, Part 6, 26-33.

[16] Henson, F.R.S. (1950) Cretaceous and Tertiary Reef Formation and Associated Sediments in Middle East. AAPG Bulletin, 34, 215-238.

[17] Dunninton, H.V. (1958) Generation, Migration, Accumulation and Dissipation of oil in Northern Iraq. In: Weeks, L.C., Ed., Habitat of Oil, AAPG Special Publication $18,1194-1251$.

[18] Tode, H.G. and Monster, J. (1970) Sulfur Isotope Abundances and Genetic Relations of Oil Accumulations in Middle East Basin. AAPG Bulletin, 54, 627-637.

[19] Burwood, R. (1976) Carbonate Source for Six Million Barrels Oil per Day-Zagros Fold Belt, Southwestern Iran. In: Palacas, J.G., Ed., Petroleum Geochemistry and Source Rock Potential of Carbonate Rocks, AAPG Studies in Geology 18, 206.

[20] Young, A., Monaghan, P.H. and Schweisberger, R.T. (1977) Calculation of Ages of Hydrocarbon in Oils: Physical Chemistry Applied to Petroleum Geochemistry. AAPG Bulletin, 61, 573-600.

[21] Ala, M.A. (1980) Chronology of Trap Formation and Migration of Hydrocarbons in the Zagros Sector of SW Iran. AAPG Bulletin, 66, 1535-1541.

[22] Ala, M.A., Kinghorn, R.R.F. and Rahman, M. (1980) Organic Geochemistry and Source Rock Characterization of the Zagros Petroleum Province, SW Iran. Journal of Petroleum Geology, 3, 61-89. https://doi.org/10.1111/j.1747-5457.1980.tb01004.x

[23] Harb. A. (2007) Petroleum Geology. Payam-Noor University Publications, Tehran.

[24] Tucker, M.E. and Wright, V.P. (1990) Carbonate Sedimentology. Wiley, Oxford. https://doi.org/10.1002/9781444314175 
Submit or recommend next manuscript to SCIRP and we will provide best service for you:

Accepting pre-submission inquiries through Email, Facebook, LinkedIn, Twitter, etc. A wide selection of journals (inclusive of 9 subjects, more than 200 journals)

Providing 24-hour high-quality service

User-friendly online submission system

Fair and swift peer-review system

Efficient typesetting and proofreading procedure

Display of the result of downloads and visits, as well as the number of cited articles Maximum dissemination of your research work

Submit your manuscript at: http://papersubmission.scirp.org/

Or contact ojg@scirp.org 